\title{
ARCHAEOLOGICAL PARASITES AS INDICATORS OF ENVIRONMENTAL CHANGE IN URBANIZING LANDSCAPES: IMPLICATIONS FOR HEALTH AND SOCIAL STATUS
}

\author{
Heather B. Trigg, Susan A. Jacobucci, Stephen A. Mrozowski, and John M. Steinberg
}

\begin{abstract}
Using archaeological data of two human intestinal parasites from seventeenth-to early twentieth-century contexts, we explore the intersection of biological and cultural variables that shaped the ecology of cities in northeastern North America during the modern period. These parasites are useful because they require a developmental period in the soil, thus providing a link between human activities and changing environments. Prior to the last decades of the eighteenth century, Trichuris eggs dominate the archaeoparasitological assemblage. Around 1800, there is a shift to increasing proportions of Ascaris eggs, which appears to be largely complete by 1850 - a period of increasing urbanization in the northeast United States. Both environmental and behavioral factors play a role in this shift and include the relationship between parasite biology and changing microenvironments, attempts to deal with waste, and use of urban spaces. During this period, poorer households would likely have been at greater risk of parasites because of the ways they used yard spaces, their delayed access to sanitary technology, and the changing nature of urban vegetation in densely occupied neighborhoods.
\end{abstract}

Utilizando datos arqueológicos sobre dos parásitos intestinales humanos recuperados en contextos que datan desde el siglo XVII hasta principios del siglo XX, exploramos la intersección entre las variables biológicas y culturales que dieron forma a la ecología de las ciudades en el noreste de América del Norte durante el período moderno. Estos parásitos son indicadores útiles porque requieren un período de desarrollo en el suelo, proporcionando así un vínculo entre las actividades humanas y su entorno cambiante. Antes de las últimas décadas del siglo XVIII, los huevos de Trichuris dominan el conjunto arqueoparasitológico. Esto cambia alrededor de 1800 con un incremento en la proporción de huevos de Ascaris, aumento que parece concluir alrededor de 1850 - un período de urbanización creciente en el noreste de Estados Unidos-. Factores ambientales y comportamentales influyeron en este cambio. Estos incluyen la relación entre la biología de los parásitos y los microambientes cambiantes, las diferentes estrategias de manejos de desechos y el uso de los espacios urbanos. Durante este período es probable que los hogares más pobres estuvieran en mayor riesgo de tener parásitos debido a la forma en que se utilizaban los espacios abiertos, retrasos en el acceso a la tecnología sanitaria y la naturaleza cambiante de la vegetación urbana en los barrios densamente ocupados.

$\mathrm{W}$ hen the growth of urban communities began its dramatic rise in the mideighteenth century, a little over 5 percent of the world's population lived in cities. Today, more than 75 percent of the population of developed countries lives in urban communities (Dodman et al. 2013:1-4), and this rapid urbanization has been accompanied by ecological changes whose social implications are less well documented (Pickett et al. 2001). Understanding current and future urban ecosystems involves determining the causal relationships that may exist between biological, physical, and cultural variables, an important consideration given the kinds of wealth disparities that commonly exist in cities (Alcoforado and Andrade 2008:259). Archaeological contexts, with their potential to address both culture and environment simultaneously, afford a unique perspective for understanding the trajectory and interplay of these forces.

\footnotetext{
Heather B. Trigg, Stephen A. Mrozowski, and John M. Steinberg $\square$ Andrew Fiske Center for Archaeological Research, University of Massachusetts Boston, 100 Morrissey Blvd., Boston, MA 02125, USA (heather.trigg@umb.edu, corresponding author)

Susan A. Jacobucci — Veterans Upward Bound, University of Massachusetts Boston, 100 Morrissey Blvd., Boston, MA 02125, USA

American Antiquity 82(3), 2017, pp. 517-535

Copyright (C) 2017 by the Society for American Archaeology. This is an Open Access article, distributed under the terms of the Creative Commons Attribution licence (http://creativecommons.org/licenses/by/4.0/), which permits unrestricted re-use, distribution, and reproduction in any medium, provided the original work is properly cited.
}

doi:10.1017/aaq.2017.6 
In this paper, we explore the intersection of a variety of biological and cultural variables that have helped shape the rich mosaic of culturally influenced microenvironments that constitute urban areas, and we link these to consequences for the health of people with disparate social standings. As cities developed, people altered urban ecologies and changed the ways they created and used their landscape. Such changes are manifest on a variety of scales, from alterations in soil microfauna to the increase in the geographic range of plant species due to the heat island effect (Gilbert 1989; Pickett et al. 2001). Urban environments, in turn, had an effect on health that was recognized in North America during the eighteenth and nineteenth centuries (Melosi 2008). These impacts were significant from both biological and cultural perspectives. For example, the sanitary reform movement in the nineteenth century evolved as a response to outbreaks of epidemics diseases, which were viewed as being caused by environmental conditions (Duffy 1990).

We examine the processes of urbanization from the vantage of the archaeological remains of two parasites that inhabit the human bodyAscaris lumbricoides (roundworm, maw worm) and Trichuris trichiura (whipworm). People become infected with these parasites when their fertile eggs are ingested, often with contaminated food and water (Ash and Orihel 1990:134, 138). Once eggs are ingested and pass through the stomach, they hatch in the intestines. Trichuris larvae mature in the small intestines and establish themselves in the colon. Ascaris larvae move outside the gut, into the circulatory system, and travel through other organs of the body, spending about two weeks in the lungs before moving into the trachea and finally entering the small intestines, where they mature (Davey 1966:168169, 177).

Female Ascaris worms mature to produce eggs within 60 to 90 days, female Trichuris worms after 60 to 70 days. Adult Ascaris worms live for approximately one to two years, but data on Trichuris are less consistent, with lifespan estimates varying from one to 10 years (Ash and Orihel 1990:134, 138). Each Ascaris female has the potential to produce 200,000 to 240,000 eggs per day; a female Trichuris, on the other hand, produces many fewer-from 3,000 to 20,000 eggs per day (World Health Organization [WHO] 1981:59). The ova of both species are expelled from the human body in feces and must spend two to three weeks outside of their host and in soil in order to become infective (Ash and Orihel 1990). During this time, parasite ova embryonate or undergo larval development. Undeveloped eggs are not infective; that is, if they are consumed, they will not produce disease. During this process, the larva is sheltered within the egg, but the period in the soil exposes them to environmental conditions, which can affect their development, viability, and transmission (Maya et al. 2010; Pecson et al. 2007). These parasites are useful for understanding changing environmental conditions because they spend part of their life cycle in the soil and are therefore susceptible to the conditions of anthropogenic environments.

Although these parasites rarely cause the death of their hosts, heavy parasite loads can cause a variety of illnesses and affect children's development. Trichuris infections tend to be mild, possibly asymptomatic in cases of light parasite loads, but very heavy loads may cause intestinal obstruction (Davey 1966). Ascaris infections also tend to be mild, but they can be more dangerous in part because the worms leave the gut during their life cycles and migrate through the body. Ascaris can cause blockages of the liver, bile, and pancreatic ducts, peritonitis, and liver failure, as well as contributing to pneumonia and appendicitis (Davey 1966). The parasites can cause allergic reactions and may be involved in reduced immune responses, and malabsorption of nutrients is associated with Ascaris infections (Bradley and Keymer 1984). The mortality associated with the parasites may be low, but its contribution to other diseases is not well studied and is probably significant (Bradley and Keymer 1984). Epidemiologists working on current infections suggest that the real costs of these diseases are unknown and probably underestimated (WHO 1981). Significantly, both parasites appear to affect children more heavily.

Archaeological evidence indicates that these parasites have plagued people for millennia, having evolved with hominids at least since Homo erectus (Bouchet et al. 2003; Leles 
et al. 2010; Reinhard and Araújo 2012), and they are among the most common parasites today (WHO 2012). They commonly co-occur, but a number of researchers have noted a shift through time in the numerical dominance of one parasite, Trichuris, to the other, Ascaris (Leles et al. 2010; Trigg and Jacobucci 2008) - a transition, we argue, that is related to changing environmental conditions brought about by both intentional and unintentional activities in cities. Because of the long relationship between these parasites, people, and the environment, we gain a window onto the complex processes of urbanization over the past 400 years. Using parasite data from a number of archaeological contexts, we explore the timing and causes of this shift in northeastern North America, focusing on the complex anthropogenic ecosystems that were deliberately and inadvertently created in cities and the impact of this shift on human health.

\section{Archaeological Analysis, Culture, and Environment}

Data on these and other parasites gleaned from archaeological contexts help complete biological and cultural pictures of urban life (Mrozowski 2006; Reinhard 2000). The relationship between parasites, health, status of households, and household composition provides a contrast with material culture representations of identity (Fisher et al. 2007; Mrozowski 2006; Reinhard, Mrozowski, and Orloski 1986). In colonial Newport, Rhode Island, parasite loads correlate with occupation and status levels (Reinhard, Mrozowski, and Orloski 1986). In a study of sites in Albany, New York, Fisher and colleagues (2007) identified lower parasite loads in one household, which they attribute to the inhabitants' knowledge of and access to medicines to treat intestinal parasites. Recent work by Reinhard et al. (2013) and others (Searcey et al. 2013) shows that parasite diseases differed between North America and Europe. Parasites associated with meat consumption are much less common in New England than Europe, suggesting that colonists quickly developed methods of food preparation that eliminated such parasites (Reinhard et al. 2013; Searcey et al. 2013). In historic North America, the archaeoparasitological record is distinct for its lack of food-borne parasites, but the record in both North America and Europe is dominated by Trichuris trichiura and Ascaris lumbricoides.

While the adult worms are rarely recovered, the eggs of Ascaris and Trichuris (Figure 1) have been found in a number of archaeological deposits, particularly coprolites, privies, cesspools, and other features associated with human waste. Archaeoparasitological studies often rely on coprolite analysis from burials (Rácz et al. 2015), middens (Fugassa et al. 2011; Jiménez et al. 2012), or privy-type deposits (Fisher et al. 2007), although, in some instances, parasites have been found in mummies (Kumm et al. 2010), wells, pits (Pike 1968), and living surfaces in and around buildings (Jones 1985; Jones et al. 1988). Because of the focus on coprolites and privy contexts, investigations have been useful for addressing parasitism on individual or household levels (Fisher et al. 2007; Kumm et al. 2010; Reinhard 1988, 2000, 2008; Reinhard, Mrozowski, and Orloski 1986). In historic contexts, where researchers can connect the social status of known individuals to the parasites, investigations are particularly powerful for understanding the relationship between health and status.

While much archaeoparasitological research has focused on individuals and households, parasites are also useful for examining interactions between people and their environments on a larger scale (Reinhard 1992). Because geoparasites such as Ascaris and Trichuris require human hosts for reproduction and must spend some of their life cycle outside the human body, they can be used to investigate peoples' migration through (Araújo et al. 2008) and occupation of (Reinhard 1985, 1988, 1992) different habitats. For example, Hevly and colleagues (1979) determined that prehistoric inhabitants of Arizona may have built their homes in relatively arid locations but had at some point visited moister microenvironments of canyon bottoms, where they acquired parasite infections. While parasites generally reflect local environmental conditions, aggregated data of their presence can be used to track changing conditions on a larger scale. Reinhard (1992) used the fact that Strongyloides requires moist soil conditions to argue that eggs recovered from 


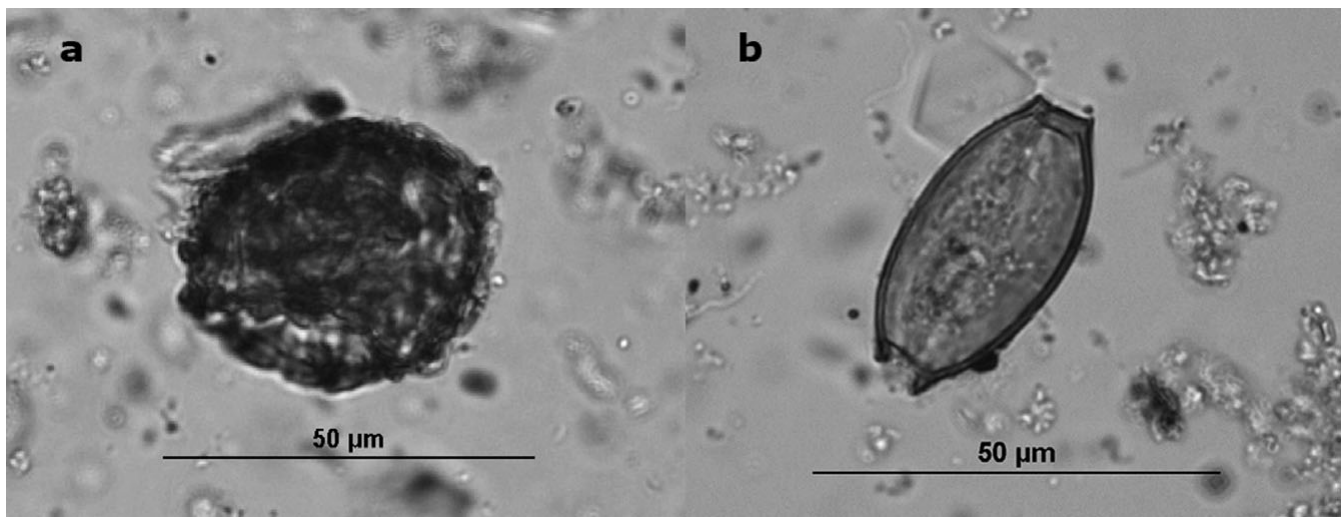

Figure 1. (a) Ascaris ovum from Boston's Cross Street Privy, (b) Trichuris ovum from Boston's Cross Street Privy—note the two opercula.

prehistoric contexts in the American Southwest indicate that the environment was wetter in the past than in the present.

Because geoparasites, such as Ascaris and Trichuris, spend part of their life cycle in the soil, changes in the environment may affect their distribution and abundance, and the research presented here investigates the relationship between the peoples' use of urban habitats and parasitic infections they may carry. By synthesizing archaeoparasitological data from a number of historic sites in the eastern United States, we examine the relationship between the development of urban spaces and the changing proportions of Trichuris trichiura and Ascaris lumbricoides. Today, Ascaris is the more common of the two parasites, infecting an estimated one billion people worldwide (Bethony et al. 2006), but this has not always been the case. Data from archaeological sites suggest that Trichuris was more common in prehistoric European and North American contexts (Bouchet et al. 2003; Bundy and Cooper 1989; Leles et al. 2010).

These parasites have similar although not identical environmental tolerances, life cycles, and histories, and the differences may have important implications for the relationships these parasites have with their human hosts and the environment. Ultimately, however, the reasons for the shift from Trichuris to Ascaris are not well understood. Leles and colleagues (2010) suggest several reasons for the lack of Ascaris ova in South American archaeological samples and the change from the archaeological to the present- day distribution, including the use of medicines, prehistoric human behavior, and taphonomic processes. What they do not explore is the possibility that changing environmental conditions may have influenced parasite distributions. Using well-dated archaeological deposits, we identify when the shift from Trichuris to Ascaris occurred in the cities of northeastern North America and offer some additional reasons that link the change to a set of biological, ecological, and cultural variables that had wide-ranging influence on urban life.

\section{Archaeological Data}

To trace the shift from Trichuris to Ascaris and the underlying causes, we surveyed archaeoparasitological literature for sites in the northeast United States and gathered data on parasite remains from archaeological contexts dating from the seventeenth through the early twentieth centuries, at which time privies declined in use in urban areas in favor of sewers (Driscoll 1994; Geismar 1993; Mrozowski 2006, 2014). These data, although collected by several researchers, follow protocols developed by Karl Reinhard (see Warnock and Reinhard 1992). Hevly and colleagues (1979) first used these protocols when they found parasite eggs in latrine samples processed for pollen analysis. Reinhard, Mrozowski, and Orloski (1986) modified typical pollen extraction methods, which optimized parasite recovery with less damage to parasite eggs. Although other methods for recovering parasite 
eggs exist, Reinhard's procedure is considered to be the most effective (Dufour and Le Bailly 2013). We follow this procedure, and therefore data presented here are directly comparable between contexts and cities, making this the largest quantified data set derived from the most effective parasite recovery method.

Ova recovery rates are influenced by the amount of fecal material in the deposits (Jones 1985), the depositional environment (Reinhard, Confalonieri, et al. 1986), and peoples' parasite loads. In the case of latrine sediments, the rapid deposition in deep, protected, and anaerobic environments optimized preservation. Privies, especially those in the Northeast, provide anaerobic conditions that favor the preservation of parasite ova (Karl Reinhard, personal communication 2016). However, taphonomic conditions have been implicated in the differential preservation of Trichuris and Ascaris ova (Rácz et al. 2015). Ascaris eggs have several separable layers, whereas Trichuris eggs have one layer, and their bi-opercular morphology (Figure 1) makes them more susceptible to fracture. In general, we found very good preservation of both types of eggs in our study sites. We controlled for taphonomic factors by using data only from privy contexts rather than from the full suite of archaeological contexts, such as yards, trenches, and living surfaces, which have yielded parasite eggs.

We selected only those data where egg counts for both parasites were given. Although other parasites were identified in some samples, Ascaris and Trichuris were by far the most common taxa, and our analysis considers only these parasites. For each site or deposit, we used reported dates or estimated the date of the deposit based on the information given.

The selected sites are primarily urban or at least constitute more densely populated areas than their surroundings (Figure 2; Table 1). From the seventeenth and eighteenth centuries, we have deposits from four sites in New England. The earliest data come from the Cross Street privy in Boston, Massachusetts (Heck and Balicki 1998; Jacobucci 2009). The deposits analyzed are associated with the household of Katherine Naylor, a merchant's widow, and date to between 1670 and 1703. Information was also gathered from three households from the eighteenth century in Newport, Rhode Island. The earliest of these, dating to about 1730 , is a privy associated with a shopkeeper (Gallagher 2006; Hodge 2007). The second, dating to about 1750 , is associated with a merchant's house (Mrozowski 2006; Reinhard, Mrozowski, and Orloski 1986). The third privy, associated with a middle class household, dates to about 1770 (Mrozowski 2006; Reinhard, Mrozowski, and Orloski 1986).

Privies from Albany, New York, span the mid-eighteenth through nineteenth centuries and represent a diverse population that included boardinghouse residents, laborers, merchants, ship captains, and politicians (Fisher et al. 2007). Fisher and colleagues (2007) investigated eight sites for parasites, and we use data from 23 of the excavated privies. Eight privies from New York City's Five Points neighborhood date from the mid-eighteenth to the early twentieth centuries and provide parasite data from households of varying economic class (Reinhard 2000). Four privies in Wilmington, Delaware, provide data from the late eighteenth century to early twentieth centuries. These contexts were associated with laborers who rented their residences (Fries et al. 1990). From the nineteenth century, we have data from the middle-class African American families who occupied a tenement behind Boston's African Meeting House (Gallagher et al. 2008). Samples examined from Harpers Ferry, West Virginia, date from the late nineteenth to early twentieth centuries and yielded parasite data from a wealthy household and a boardinghouse (Reinhard 1994). Three samples, one from each of three privies in Sleepy Hollow, New York, yielded parasite ova (Reinhard 2007). These deposits dated to late nineteenth to early twentieth centuries. Where there were multiple samples from a particular privy or layer, we examined each sample separately.

\section{Results}

The parasite egg counts indicate a great deal of variability among samples, but in general there is a decline through time in the number of total eggs per sample (Table 2). Preservation and context can dramatically affect the quantities 


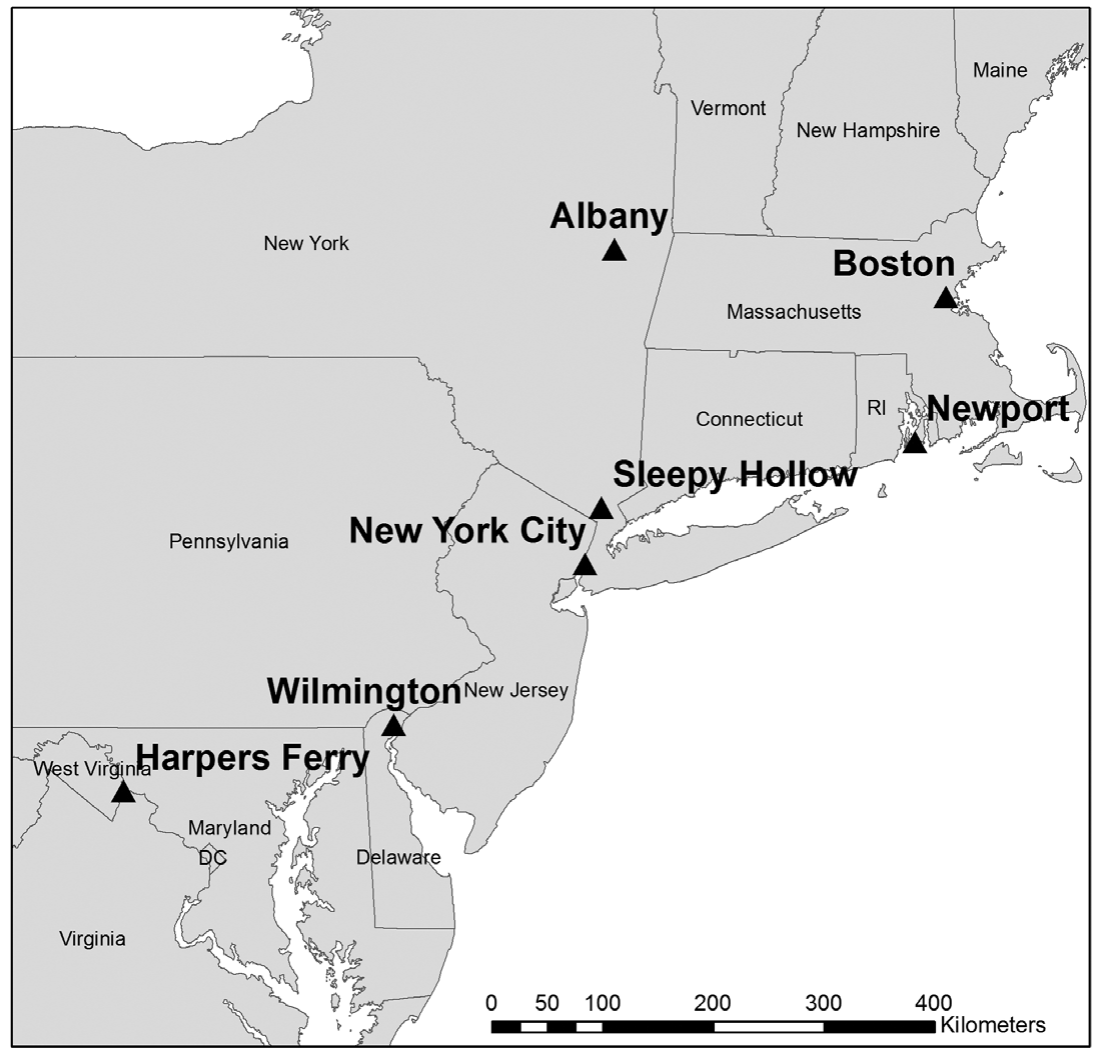

Figure 2. Cities yielding parasite ova data used in this study.

of eggs recovered, which is demonstrated in the wide variation in the number of eggs recovered (Table 2). To mitigate variables such as preservation and differences in parasite egg production, we focus on the ubiquity and relative proportions of ova rather than the absolute numbers of eggs.

The ubiquity of the different parasites provides one indication of their prevalence and suggests an increase in the presence of Ascaris and a decrease in Trichuris thorough time. In samples dating to 1800 or earlier, 92 percent have Ascaris eggs and 96 percent have Trichuris eggs (Table 2). After 1800, 73 percent of samples have Trichuris eggs and 98 percent have Ascaris eggs. The prevalence of these taxa as measured by their ubiquity indicates a shift from Trichuris to Ascaris.

Relative proportions of Ascaris and Trichuris ova were calculated from the sum of both taxa and exclude the small number of other parasites identified (Table 2). We aggregated these data by decade using the earliest possible decade in ranges with large spans, ordered the proportions chronologically, and plotted the results (Figure 3). Data from individual sites show variation, but the general trend is an increasing proportion of Ascaris eggs through time (Figure 3). Prior to the last decades of the eighteenth century, Trichuris eggs dominate the assemblage. Around 1800, a predominance of Trichuris eggs gave way to a predominance of Ascaris eggs, and this shift appears to have been largely complete by 1850 .

The difference in egg production between these taxa may have a bearing on the number of eggs recovered, but is not the cause of the shift from one taxon to the other. A female Ascaris produces 10 times more eggs than a female Trichuris (WHO 1981). The largest number of Trichuris eggs in a sample is 15,500, and the largest number of Ascaris is 310,999 eggs, more than 20 times greater-twice as many as would be expected from a simple difference in 
Table 1. Sources of Parasite Data.

\begin{tabular}{|c|c|c|c|}
\hline Location & Site/Context & Date Range & Source \\
\hline Boston, MA & Cross Street & $1670-1703$ & Jacobucci 2009 \\
\hline Newport, RI & Wanton-Lyman Hazard House & $1700-1739$ & Jacobucci 2009; Gallagher 2006 \\
\hline Newport, RI & Brown & $1730-1750$ & Reinhard, Mrozowski, and Orloski 1986 \\
\hline Newport, RI & Tate & $1750-1770$ & Reinhard, Mrozowski, and Orloski 1986 \\
\hline Albany, NY & Picotte Privy 4 & $1760 \mathrm{~s}$ & Fisher et al. 2007 \\
\hline Albany, NY & Picotte Privy 5 & $1780 \mathrm{~s}$ & Fisher et al. 2007 \\
\hline Albany, NY & Pearl St & $1780 \mathrm{~s}$ & Fisher et al. 2007 \\
\hline Albany, NY & Picotte Privy 1 & $1790 \mathrm{~s}$ & Fisher et al. 2007 \\
\hline Albany, NY & SUPG stone privy $(1 / 20)$ & $1800 \mathrm{~s}$ & Fisher et al. 2007 \\
\hline Albany, NY & SUPG Well, Privy & $1800 \mathrm{~s}$ & Fisher et al. 2007 \\
\hline Albany, NY & SUPG Wood Privy (38) & $1800 \mathrm{~s}$ & Fisher et al. 2007 \\
\hline Albany, NY & Picotte Privy 6 & $1800 \mathrm{~s}$ & Fisher et al. 2007 \\
\hline Albany, NY & Court of Appeals Privy & $1800 \mathrm{~s}$ & Fisher et al. 2007 \\
\hline Albany, NY & SUPG Privy, stone (3) & $1810 \mathrm{~s}$ & Fisher et al. 2007 \\
\hline Albany, NY & Picotte Privy 3 & $1830 \mathrm{~s}$ & Fisher et al. 2007 \\
\hline Albany, NY & 40 Howard Privy 2 & $1830 \mathrm{~s}$ & Fisher et al. 2007 \\
\hline Albany, NY & 40 Howard Privy 3 & $1830 \mathrm{~s}$ & Fisher et al. 2007 \\
\hline Albany, NY & Quackenbush Privy, barrel & $1830 \mathrm{~s}$ & Fisher et al. 2007 \\
\hline Albany, NY & Picotte Privy 2 & $1850 \mathrm{~s}$ & Fisher et al. 2007 \\
\hline Albany, NY & Picotte Privy 11 & $1850 \mathrm{~s}$ & Fisher et al. 2007 \\
\hline Albany, NY & Picotte Privy 12 & $1850 \mathrm{~s}$ & Fisher et al. 2007 \\
\hline Albany, NY & 40 Howard Privy 5 & $1850 \mathrm{~s}$ & Fisher et al. 2007 \\
\hline Albany, NY & SUPG Privy, wood (6/31) & $1860 \mathrm{~s}$ & Fisher et al. 2007 \\
\hline Albany, NY & Picotte Privy 9 & $1860 \mathrm{~s}$ & Fisher et al. 2007 \\
\hline Albany, NY & Picotte Privy 10 & $1860 \mathrm{~s}$ & Fisher et al. 2007 \\
\hline Albany, NY & Quackenbush Privy, wood & $1880 \mathrm{~s}$ & Fisher et al. 2007 \\
\hline Wilmington, DE & Feature 37 & $1790-1820$ & Fries et al. 1990 \\
\hline Wilmington, DE & Feature 14 & $1790-1830$ & Fries et al. 1990 \\
\hline Wilmington, DE & Feature 6 & $1880-1920$ & Fries et al. 1990 \\
\hline Wilmington, DE & Feature 5 & $1880-1920$ & Fries et al. 1990 \\
\hline Five-Points, NYC & Feature AF & $1793-1812$ & Reinhard 2000 \\
\hline Five-Points, NYC & Feature C & $1800-1810$ & Reinhard 2000 \\
\hline Five-Points, NYC & Feature E & $1800-1833$ & Reinhard 2000 \\
\hline Five-Points, NYC & Feature B V & $1810-1843$ & Reinhard 2000 \\
\hline Five-Points, NYC & Feature N IV & $1812-1830$ & Reinhard 2000 \\
\hline Five-Points, NYC & Feature AK & $1820-1829$ & Reinhard 2000 \\
\hline Five-Points, NYC & Feature J & $1840-1860$ & Reinhard 2000 \\
\hline Boston, MA & 22 Joy Street & $1818-1835$ & Gallagher et al. 2008 \\
\hline Sleepy Hollow, NY & 104 Valley St. Bag 24 & $1890-1900$ & Reinhard 2007 \\
\hline Sleepy Hollow, NY & 104 Valley St. Bag 26 & $1890 \mathrm{~s}$ & Reinhard 2007 \\
\hline Sleepy Hollow, NY & 112 Valley St. Bag 78 & $1890-1905$ & Reinhard 2007 \\
\hline Harpers Ferry, WV & Hurst & $1884-1920$ & Reinhard 1994 \\
\hline Harpers Ferry, WV & Boardinghouse & 1891-1907 & Reinhard 1994 \\
\hline Harpers Ferry, WV & Feature 21, Privy & $1900-1930$ & Reinhard 1994 \\
\hline
\end{tabular}

egg production. Moreover, Ascaris and Trichuris have been in association for thousands of years in Europe and at least hundreds of years in North America. Were the shift in proportions seen in the archaeological record merely the result of ascarids outproducing trichurids, this transition should have taken place earlier in their coexistence.
To explore the timing of the decline in more detail, we grouped the proportion data into 50 -year intervals (Figure 4). The percentage of Ascaris is below 50 percent during the first 100 years of the study period and is greater than 80 percent during roughly the last 100 years. The middle 50-year period appears to be transitional. The median percentage of Ascaris eggs for both 
Table 2. Counts and Proportions of Ascaris and Trichuris Ova in Each Context.

\begin{tabular}{|c|c|c|c|c|c|c|}
\hline Date range & Location & Site/Context & Ascaris $\mathrm{Ct}$. & Trichuris Ct. & $\%$ Ascaris & $\%$ Trichuris \\
\hline $1670-1695$ & Boston & Cross Street & 128 & 250 & 33.86 & 66.14 \\
\hline $1670-1703$ & Boston & Cross Street & 22 & 35 & 38.60 & 61.40 \\
\hline 1700-1739 & Newport & Wanton-Lyman-Hazard House & 235 & 298 & 44.09 & 55.91 \\
\hline $1730-1750$ & Newport & Brown & 200 & 5,600 & 3.45 & 96.55 \\
\hline $1750-1770$ & Newport & Tate & 10,300 & 15,500 & 39.92 & 60.08 \\
\hline $1760 \mathrm{~s}$ & Albany & Picotte $3 / 112$ & 62,710 & 2,508 & 96.15 & 3.85 \\
\hline $1780 \mathrm{~s}$ & Albany & Picotte 6/126 & 223,248 & 3,763 & 98.34 & 1.66 \\
\hline $1780 \mathrm{~s}$ & Albany & Pearl St 1 & 207 & 2,900 & 6.66 & 93.34 \\
\hline $1780 \mathrm{~s}$ & Albany & Pearl St 3 & 266 & 444 & 37.46 & 62.54 \\
\hline $1790 \mathrm{~s}$ & Albany & Picotte $1 / 96$ & 89,675 & 3,763 & 95.97 & 4.03 \\
\hline 1790-1820 & Wilmington & Feature 37 & 40 & 190 & 17.39 & 82.61 \\
\hline 1790-1820 & Wilmington & Feature 37 & 1,307 & 351 & 78.83 & 21.17 \\
\hline 1790-1820 & Wilmington & Feature 37 & 672 & 165 & 80.29 & 19.71 \\
\hline 1790-1830 & Wilmington & Feature 14 & 9 & 24 & 27.27 & 72.73 \\
\hline 1790-1830 & Wilmington & Feature 14 & 0 & 20 & 0.00 & 100.00 \\
\hline 1790-1830 & Wilmington & Feature 14 & 51 & 84 & 37.78 & 62.22 \\
\hline 1790-1830 & Wilmington & Feature 14 & 89 & 91 & 49.44 & 50.56 \\
\hline 1790-1830 & Wilmington & Feature 14 & 0 & 37 & 0.00 & 100.00 \\
\hline 1793-1812 & Five-Points & Feature AF & 302 & 226 & 57.20 & 42.80 \\
\hline 1800-1810 & Five-Points & Feature C & 215 & 435 & 33.08 & 66.92 \\
\hline 1800-1833 & Five-Points & Feature E & 2,212 & 3,726 & 37.25 & 62.75 \\
\hline $1800 \mathrm{~s}$ & Albany & SUPG $1 / 20$ & 4,973 & 104 & 97.95 & 2.05 \\
\hline $1800 \mathrm{~s}$ & Albany & SUPG 5/9 & 310,999 & 12,181 & 96.23 & 3.77 \\
\hline $1800 \mathrm{~s}$ & Albany & SUPG 7/38 & 5,150 & 1,598 & 76.32 & 23.68 \\
\hline $1800 \mathrm{~s}$ & Albany & Picotte $4 / 148$ & 1,254 & 314 & 79.97 & 20.03 \\
\hline $1800 \mathrm{~s}$ & Albany & Court of Appeals 15 & 497 & 0 & 100.00 & 0.00 \\
\hline 1810-1837 & Five-Points & Feature B V & 1,295 & 1,716 & 43.01 & 56.99 \\
\hline $1810 \mathrm{~s}$ & Albany & SUPG 3 & 25,199 & 678 & 97.38 & 2.62 \\
\hline $1812-1830$ & Five-Points & Feature N IV & 1,638 & 1,563 & 51.17 & 48.83 \\
\hline $1818-1835$ & Boston & 22 Joy Street & 73 & 11 & 86.90 & 13.10 \\
\hline 1818-1835 & Boston & 22 Joy Street & 51 & 7 & 87.93 & 12.07 \\
\hline $1820-1829$ & Five-Points & Feature AK & 1,697 & 566 & 74.99 & 25.01 \\
\hline $1830 \mathrm{~s}$ & Albany & Picotte $5 / 113$ & 251 & 0 & 100.00 & 0.00 \\
\hline $1830 \mathrm{~s}$ & Albany & 40 Howard $1 / 2$ & 1,420 & 444 & 76.18 & 23.82 \\
\hline $1830 \mathrm{~s}$ & Albany & 40 Howard $2 / 2$ & 1,709 & 155 & 91.68 & 8.32 \\
\hline $1830 \mathrm{~s}$ & Albany & 40 Howard $3 / 3$ & 11,311 & 1,119 & 91.00 & 9.00 \\
\hline $1830 \mathrm{~s}$ & Albany & Quackenbush 3/Upper & 38,947 & 829 & 97.92 & 2.08 \\
\hline $1830 \mathrm{~s}$ & Albany & Quackenbush 4/Lower & 31,607 & 765 & 97.64 & 2.36 \\
\hline 1830-1843 & Five-Points & Feature B IV & 1,357 & 1,772 & 43.37 & 56.63 \\
\hline $1840-1860$ & Five-Points & Feature J & 295 & 2,580 & 10.26 & 89.74 \\
\hline $1850 \mathrm{~s}$ & Albany & Picotte $2 / 108$ & 1,505 & 250 & 85.75 & 14.25 \\
\hline $1850 \mathrm{~s}$ & Albany & Picotte 10/97 & 60,202 & 2,090 & 96.64 & 3.36 \\
\hline $1850 \mathrm{~s}$ & Albany & Picotte 11/147 & 1,026 & 114 & 90.00 & 10.00 \\
\hline $1850 \mathrm{~s}$ & Albany & 40 Howard 4/5 & 799 & 178 & 81.78 & 18.22 \\
\hline $1850 \mathrm{~s}$ & Albany & 40 Howard $5 / 5$ & 19,000 & 178 & 99.07 & 0.93 \\
\hline $1850 \mathrm{~s}$ & Albany & 40 Howard 6/5 & 33,561 & 1,243 & 96.43 & 3.57 \\
\hline $1850 \mathrm{~s}$ & Albany & 40 Howard $7 / 10$ & 13,851 & 888 & 93.98 & 6.02 \\
\hline $1860 \mathrm{~s}$ & Albany & SUPG 6/31 & 2,260 & 0 & 100.00 & 0.00 \\
\hline $1860 \mathrm{~s}$ & Albany & Picotte 8/40 & 448 & 0 & 100.00 & 0.00 \\
\hline $1860 \mathrm{~s}$ & Albany & Picotte 9/122 & 228 & 0 & 100.00 & 0.00 \\
\hline $1880 \mathrm{~s}$ & Albany & Quackenbush 6 & 179 & 0 & 100.00 & 0.00 \\
\hline 1880-1920 & Wilmington & Feature 6 & 107 & 21 & 83.59 & 16.41 \\
\hline 1880-1920 & Wilmington & Feature 5 & 28 & 6 & 82.35 & 17.65 \\
\hline 1884-1920 & Harpers Ferry & Hurst & 141 & 0 & 100.00 & 0.00 \\
\hline 1884-1920 & Harpers Ferry & Hurst & 5,650 & 570 & 90.84 & 9.16 \\
\hline 1884-1920 & Harpers Ferry & Hurst & 21,470 & 1,130 & 95.00 & 5.00 \\
\hline
\end{tabular}


Table 2. Continued.

\begin{tabular}{llllrrr}
\hline Date range & Location & \multicolumn{1}{c}{ Site/Context } & Ascaris Ct. & Trichuris Ct. & \% Ascaris & \% Trichuris \\
\hline $1884-1920$ & Harpers Ferry & Hurst & 2,260 & 0 & 100.00 & 0.00 \\
$1890-1900$ & Sleepy Hollow & 104 Valley St. 2021 & 0 & 4 & 0.00 & 100.00 \\
$1890-1900$ & Sleepy Hollow & 104 Valley St. 2022 & 7 & 0 & 100.00 & 0.00 \\
$1890-1905$ & Sleepy Hollow & 112 Valley St. 2046 & 130 & 6 & 96.00 & 4.00 \\
$1891-1907$ & Harpers Ferry & Boardinghouse & 570 & 570 & 50.00 & 50.00 \\
$1891-1907$ & Harpers Ferry & Boardinghouse & 90 & 0 & 100.00 & 0.00 \\
$1891-1907$ & Harpers Ferry & Boardinghouse & 2,260 & 0 & 100.00 & 0.00 \\
$1891-1907$ & Harpers Ferry & Boardinghouse & 570 & 0 & 100.00 & 0.00 \\
$1891-1907$ & Harpers Ferry & Boardinghouse & 5,090 & 570 & 89.93 & 10.07 \\
$1891-1907$ & Harpers Ferry & Boardinghouse & 1,130 & 570 & 66.47 & 33.53 \\
$1900-1930$ & Harpers Ferry & Feature 21, Privy & 850 & 280 & 75.22 & 24.78 \\
\hline
\end{tabular}

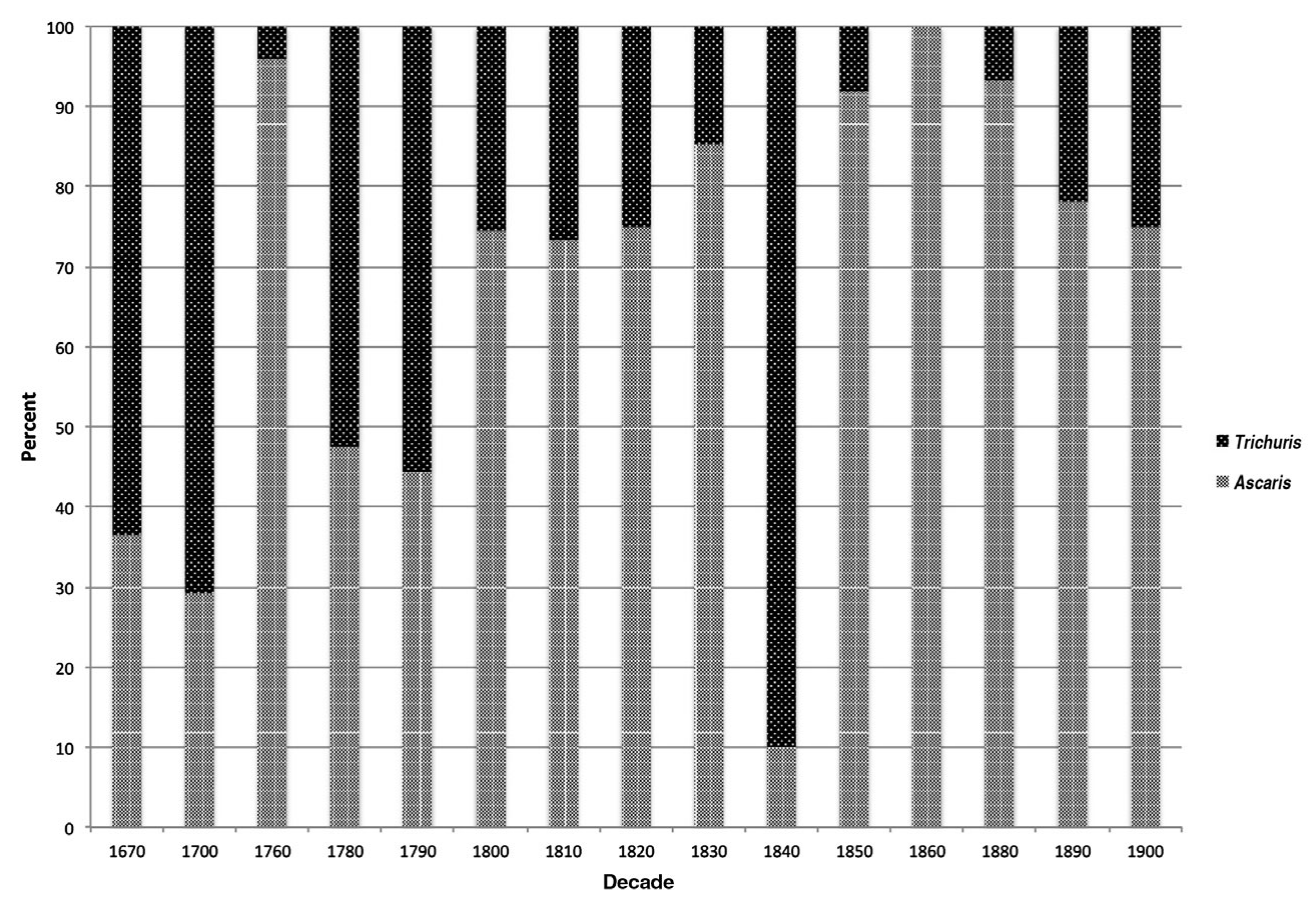

Figure 3. Proportions of Ascaris and Trichuris ova by decade. Note that the 1760 and 1840 data points are each represented by a single sample. Small sample size may account for their lack of fit with the pattern.

periods before 1750 hovers around 40 percent, while the median percentage of Ascaris eggs for both periods after 1800 is over 85 percent. There are a few samples with a low percentage of Ascaris eggs in all of the periods after 1750, but these samples tend to be outside the interquartile range. In the 1850-1900 period, those samples without Ascaris are outliers.

The shift occurs from 1800 to 1850 , a period of increasing urbanization in the northeast United States (Melosi 2008; Mrozowski 1991, 2006;
Shammas 2000). There are few large urban areas prior to the nineteenth century, but there are changes in urban population densities occurring by the 1790s through the 1820s (Shammas 2000). Population levels in the United States' largest cities, Boston, New York, Baltimore, and Philadelphia, were at their peak densities during this period (Shammas 2000). Given the timing of the shift, we suggest that cultural and ecological changes accompanying urbanization may have played a role, perhaps differentially impacting 


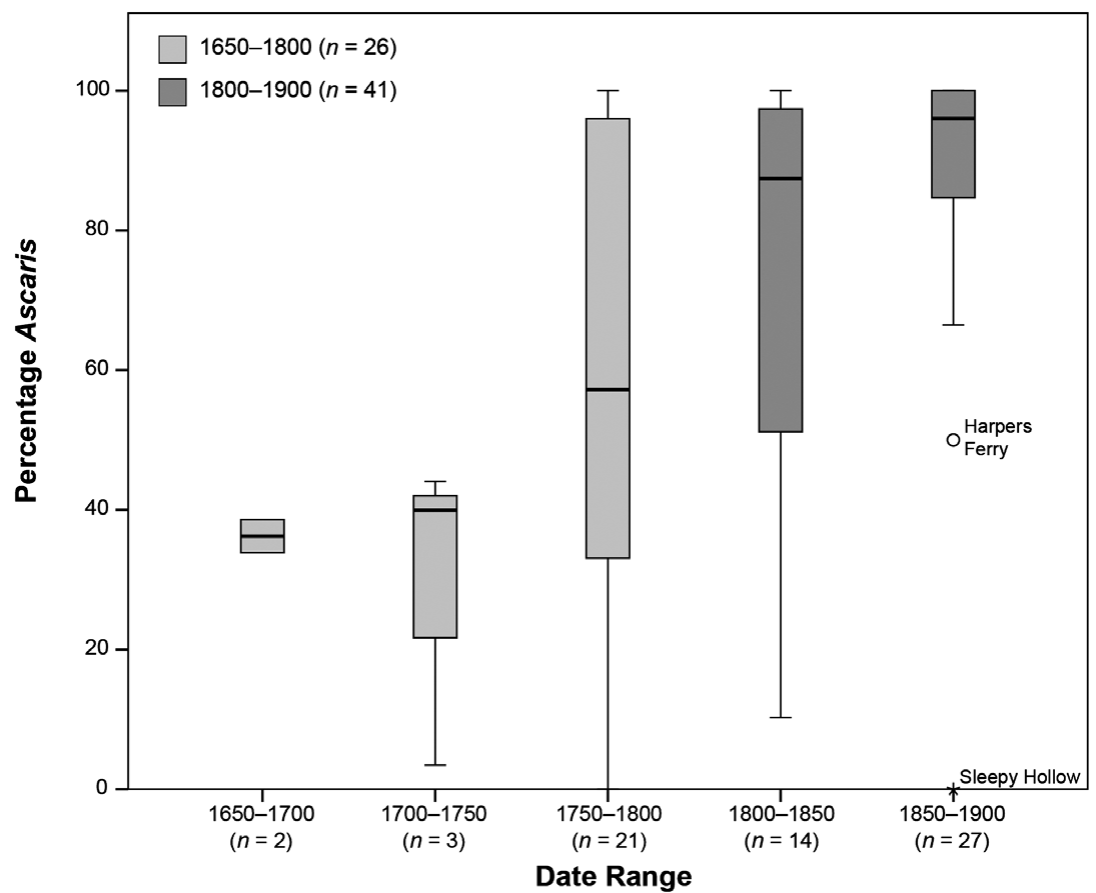

Figure 4. Box and whisker plot of the percentage of Ascaris eggs in 50-year intervals (Table 1). The box is the interquartile (IQ) range. The line in the center of each box is the median, and the whisker (line) is the case farthest from the median but still within 1.5 times the IQ. Harpers Ferry is an outlier (greater than 1.5 times the IQ range) and Sleepy Hollow is an extreme outlier (greater than 3 times the IQ range).

the viability and transmission of Ascaris and Trichuris.

There are individual samples that deviate from the general trend of increasing proportion of Ascaris (Table 1). These may be the result of cultural factors such as variability among households in wealth, status, or household composition (Mrozowski 2006; Reinhard 2000; Reinhard, Mrozowski, and Orloski 1986). Fisher and colleagues (2007) found a few privies in Albany with higher proportions of Trichuris ova than Ascaris, which is contrary to the general trend in their samples. They suggest that the use of medicines was the cause, as most nineteenthcentury medicines were more effective against Ascaris than Trichuris. They also suggest that trichurids are small and, even when the worms were expelled in feces, they might not have been noticed by the human hosts, whereas ascarids are larger, more likely to be observed, and consequently treated with vermifuges.

The trend we see toward an increasing proportion of Ascaris ova is all the more inter- esting because Trichuris infections were more difficult to treat with remedies of the eighteenth and nineteenth centuries, such as plant-based tonics and patent medicines (Mrozowski 2006; Reinhard 2000). Even today, Trichuris infections are difficult to treat (Keiser and Utzinger 2008), perhaps because the adult worm attaches itself to the intestine wall. If this pattern were merely the result of the increasing efficacy of medicinal treatments or diligence in treating infections, we would expect diminishing proportions of the more vulnerable Ascaris. This is not borne out by the data, so other factors must be influencing this shift.

Differential preservation may cause a decrease in Trichuris ova (Reinhard 1988). These eggs may be particularly sensitive to depositional factors, particularly fungal attack, which in some cases may selectively increase the decomposition of Trichuris eggs (Reinhard 1988). We acknowledge this possibility; however, if differential preservation were a consistent problem, the overall trend would be for the proportion of Trichuris 
eggs to be the lowest in the oldest samples, which would have been exposed to fungi and environmental factors longer than the most recent samples. Data presented here suggest the opposite.

Contemporary investigations of parasite transmission provide information relevant to this issue. Bakta and colleagues (1993:92) suggest that three types of factors contribute to helminth infections: ecological (the presence of ova in the soil), sociocultural (education, wealth), and genetic-specifically the human population's resistance to a particular parasite. Brooker and colleagues (2006:1149) suggest, however, that human genetic factors are not a major concern, whereas environmental conditions around homes are the most important consideration. We suggest that changing urban environmental conditions may have affected the parasites differently, and cultural practices may have influenced people's exposure to disease.

\section{Discussion}

Archaeoparasitological data from historic sites in the Northeast show a shift in the dominant parasite during the early to mid-nineteenth century, and both environmental and behavioral factors play a role in the increasing prevalence of Ascaris over Trichuris. Here we consider the relationship between parasite biology and the changing microenvironments that characterize cities, peoples' attempts to deal with human waste, and their use of space within cities. These potentially interrelated factors influence the number and type of viable parasite eggs residing in the soil, and thus those available to infect people. Geoparasite eggs exist in the soil as a result of contamination with human waste. The WHO (1981) suggests that the main pathway to children's infection is soils in which they play, primarily the dirt surrounding their homes. The use of night soil (human fecal waste) as fertilizer is a major way in which Ascaris and Trichuris infections are spread. Connecting these sorts of practices to historic patterns of disease and infection relies upon an understanding of the specific environmental conditions required for successful parasite reproduction.
One explanation for the reduction in the proportion of Trichuris eggs evident in the archaeological data is that the environment changed such that either the development of Ascaris eggs are favored or the conditions more negatively impact Trichuris. Below we consider some of the factors influencing each parasite's development and then discuss the ways that environments changed as they become increasingly urbanized.

\section{Parasite Biology and Environmental Conditions}

Ascaris is generally considered the more durable of the two parasites (Hotez et al. 2003; Maya et al. 2010), but specific data on the differences between them are generally sparse. Of the two, the environmental tolerances of Ascaris are the better known (Jiménez 2007), but emphasis is often placed on identifying lethal limits rather than conditions that are optimal for growth, which has led to somewhat ambiguous or contradictory data (Maya et al. 2010). Studies on the environmental tolerances of the parasites have generally focused on temperatures needed to inactivate larvae, but soil moisture, humidity, precipitation, sunlight, soil $\mathrm{pH}$, and other physical conditions also affect egg development (Hinz 1988). These conditions act synergistically (Maya et al. 2010).

Temperature has a major impact on the speed of development and viability of parasite eggs (Pecson et al. 2007). Ascaris larvae require soil temperatures between $15^{\circ}$ and $34^{\circ} \mathrm{C}$ for development, with $30^{\circ}$ to $33^{\circ} \mathrm{C}$ being optimal (Hinz 1988). Temperatures approach lethal levels at $38^{\circ}$ or $40^{\circ} \mathrm{C}$ (Hotez et al. 2003:13) for short periods of time, but longer periods at lower temperatures are also effective. Brown and Cort (1927) found that Ascaris eggs developed faster than Trichuris eggs, and Nolf (1932) found that Trichuris was slightly more susceptible to high temperatures than Ascaris. However, a more recent study indicates that optimal temperature for Trichuris egg development is higher than for Ascaris (Bundy and Cooper 1989:111). It is clear that data on soil temperatures that promote growth or inactivate the eggs are somewhat contradictory, but these conditions are similar for both parasites.

Other factors impact egg viability but are less understood. Beaver (1975) found significantly higher mortality of Ascaris and Trichuris eggs 
in sun-exposed as opposed to unexposed soil. Nolf (1932) found that Trichuris is more tolerant of ultraviolet light, which might indicate greater resistance to sunlight, but Ndamukong (2005) found that Trichuris is more sensitive to sun exposure than Ascaris. Both parasites are susceptible to drying (Bundy and Cooper 1989), but, due to their protective coating, Ascaris eggs are more resistant to drying than Trichuris (Jones 1985; Spindler 1929). In a field study, Spindler (1929) found that Trichuris infections correlated with soil moisture, the result of yard vegetation that kept the soil moist. Trichuris requires more moisture than Ascaris to begin development (Rudolfs et al. 1950) and Ascaris survives longer into the dry season (Ndamukong 2005).

Contemporary Ascaris infection rates are higher in urban areas than nearby rural areas (Hotez et al. 2003:11) because the urban environment, along with its higher population densities and more closely packed homes, lends itself to increasing rates of infection. Brooker and colleagues (2006) found that the microenvironmental conditions, such as the presence of vegetation, humidity, and soil temperature, immediately around homes were the most important factor for transmission, and Ascaris infections, in particular, were acquired locally. A reduction in moisture and an increase in temperature found in urban environments, along with the sticky coating on Ascaris eggs, which helps prevent drying and allows them to adhere to fingers and other objects, may select for Ascaris over Trichuris. Below we consider some of the conditions in cities that may account for an environmental reduction in humidity and an increase in temperature.

\section{Changing Urban Environments and Their Impact on Parasites}

Studies of urban ecosystems over the last 50 years document a number of differences between the biogeophysical environments of urban and rural areas (Pickett et al. 2001). Urban areas are much more patchy environments, with a variety of microclimates. Changes to city environments include alterations in temperature, humidity, soil chemistry, soil permeability, vegetation density, numbers and types of plant and animal species, air quality and particulates (Gilbert 1989; Pickett et al. 2001), and such complex and interrelated processes as organic matter decomposition, water cycling, and soil composition (Pickett et al. 2001). The factors that appear to be the most important for Ascaris and Trichuris are those that relate to temperature, humidity, the presence of vegetation, and light. These are interrelated, as vegetation cover influences temperature and humidity, and temperature shapes plant species distributions.

A dramatic effect of urbanization is the creation of the urban heat island. Gilbert (1989), for example, reports a $5^{\circ} \mathrm{C}$ difference between adjacent rural areas and the center of London on clear days. The average difference between rural and urban areas ranges between $0.5^{\circ}$ and $1.5^{\circ} \mathrm{C}$, but this difference is magnified on clear days, when such differences might reach 10 degrees (Gilbert 1989:25-26). Temperature differentials are not the only factor distinguishing urban from surrounding rural areas. Contemporary cities also have relative humidities that are up to 10 percent lower than surrounding areas (Gilbert 1989:26), and soils are generally drier (Pickett et al. 2001:139). Soil temperature and moisture regimes are important factors in the viability and speed of parasite egg development.

People also dramatically change the types and densities of vegetation (Pickett et al. 2001). Not only do they intentionally cultivate exotic ornamentals and selectively remove plants that are not desired, but they also introduce alien weeds and alter growing conditions such that some types of plants are enhanced, others inhibited. In addition, people and their activities modify the structure of plant communities, suppressing or altering succession, or creating microclimates that change plant densities and distributions (Pickett et al. 2001). Urban areas, located on formerly forested lands, tend to have less vegetation (Pickett et al. 2001). According to Pickett et al. (2001:136) these impacts, particularly on the flora, depend on a variety of cultural constructions, including building densities and differing land use. In general, there is less vegetation and fewer trees, except where they are deliberately conserved in parks or estates. The nature of vegetation cover, which may directly influence parasite ova development, is also an important factor because it relates to soil temperature and soil moisture. 
Although studies of urban ecosystems generally investigate the impacts of urbanization for the last 50 years or so, these conditions are the result of ongoing processes and feedback loops that have influenced the structure of plant and animal communities over the long term. In some places, the urban ecosystem dynamics we see today have developed over hundreds of years. Longer-term evidence for the warming of urban environments is indicated by documentary and ethnographic data showing that certain plants in cities are flowering earlier (Gilbert 1989; Mrozowski 1987; Pickett et al. 2001). Changes in urban flora and fauna have been documented in Liverpool since the industrial revolution (Greenwood 1999) and Warsaw since the eighteenth century (Mackin-Rogalska et al. 1988). These processes were acting as urban areas developed.

The intersection between peoples' choices and the environment can be seen in the urbanization process as both deliberate interventions and accidental changes with unintended consequences. Both reflect the prevailing perceptions of the time. During the nineteenth century, the ways people thought of the relationship between health and the environment had an impact on urban ecosystems. Szczygiel and Hewitt (2000) argue that the miasmic theory of disease, popular in the mid-nineteenth century, had direct implications for the character of cities. This theory held that the environment was the source of disease. Especially problematic were damp places, mud, swamps, areas with rotting or thick vegetation, and lack of air circulation. This notion led to the perception that urban spaces, especially unkempt urban spaces, were unhealthy. Sanitary and progressive reform movements considered dense foliage and dampness in cities to be two sources of disease and mounted campaigns to rehabilitate such environments (Melosi 2008; Szczgiel and Hewitt 2000). Late in the nineteenth century, Fredrick Law Olmstead and others sought to redress society's ills by creating healthy environments (Szczgiel and Hewitt 2000) and improving on the aesthetic quality of the landscapes for the good of their communities. The concern about the health particularly in urban spaces eventually led to the parks movement, which created spaces such as Central Park in New York, the Emerald Necklace in Boston, and Riverside
Park in Chicago (Szczgiel and Hewitt 2000). The emphasis on trees and well-drained landscapes that were shaded, but not excessively so, and landscapes that were manicured, dry, and controlled would have selected for the more resistant Ascaris, which could tolerate the drier conditions and whose sticky outer coating allowed it to adhere better to vegetation.

The population density of urban spaces and the increasing pace of urbanization in the early nineteenth century would also have increased the temperature of cities. While the heating effect alone is unlikely to cause a decline in the proportion of Trichuris, the environmental changes that accompanied the development of densely occupied urban areas would have, as a matter of consequence, reduced vegetation and humidity. These would have produced an environment that was less conducive to parasites, especially the more vulnerable Trichuris.

\section{Cultural Factors Relating to the Change in Parasites: The Use of Space and Sanitation}

In addition to the alterations in physical environment that characterize urbanized areas, peoples' attempts to use or deal with waste altered their exposure to infective parasite ova. Until the late nineteenth century, people used urban yard space for waste and water management, as well as for gardening and the keeping of animals such as pigs (Mrozowski 1991, 2006). The use of night soil as fertilizer may also play a role in the transmission of human parasites (Mrozowski 2006; Reinhard, Mrozowski, and Orloski 1986). The use of backlots for food production may have been the source of parasite infection for an entire household.

By the nineteenth century, this practice subsided in urban areas. Mrozowski (2006) found that the backyards of the nineteenth-century boardinghouse lots in Lowell, Massachusetts, were not used for food production and not many parasite ova were recovered (Reinhard 1989). When backlots became infrequently used for food production, parasites remained a problem, particularly for younger children who played in the dirt. The change in the use of backlots may have also selected for parasites such as Ascaris, which were more persistent in the soil, could adhere to objects and fingers, and could tolerate 
the lower level of vegetation that characterized urban backlots. Parasite biology suggests that a reduction in vegetation and the decreased use of yards for food production, along with night soil as fertilizer, would have favored Ascaris eggs even while providing an unfavorable environment for either parasite.

From the late eighteenth century well into the nineteenth century, nightmen used bucket and cart methods to remove human waste from homes and privies in the Northeast (Geismar 1993). Cleaning privies may have introduced eggs into the soil if contents spilled as the privy was being emptied. Fisher and colleagues (2007) suggest that changes in privy technology and waste disposal in nineteenth-century Albany resulted in the reduction in parasite loads evident in their data. The use of plumbing and sewerage, as long as it functioned properly, would have helped to reduce parasitic infections, as fecal material and eggs were removed from yards where children played.

By the first quarter of the nineteenth century, cities in the northeast attempted to deal with human waste by systematically removing and compositing it. Beginning around 1840, northeast cities created legislation designed to reduce human waste, sometimes by collecting and dumping it into large piles at the edge of or outside cities (Roberts and Barrett 1984). The high internal temperatures of such compost piles can destroy parasite eggs (Jensen et al. 2009). By the mid-nineteenth century, human waste was sold as a component of poudrette, a fertilizer made from a combination of dried human waste mixed with charcoal and gypsum (Roberts and Barrett 1984). In eastern cities such as Baltimore and Philadelphia, human waste, along with other refuse, was collected in piles, shipped from urban centers, and made into poudrette (Roberts and Barrett 1984). The use of poudrette as fertilizer would probably have reduced both parasites but may have favored Ascaris, which is more tolerant of changes to $\mathrm{pH}$ and drying.

The transfer of food production from household backlots and the rise of specialized truck farms and larger-scale agricultural production may have also contributed to the reduction in parasites in general and the selection of the more durable Ascaris. The early to mid-nineteenth cen- tury saw the removal of food production from the cities to the countryside (Mrozowski 2006; Tarr 1975). Shifting food production from urban yards into rural farms may have impacted the parasites in two ways. First, the deliberate use of feces as fertilizer in house lots would have stopped, and parasite eggs would no longer be transferred from produce grown in yards to the table (Mrozowski 2006). Second, moving food production outside cities would have increased the time between when parasites are shed and when they would have been consumed. This may have selected for the more hardy Ascaris eggs, but ultimately may have allowed eggs to pass through their infective period without being consumed. The production of poudrette, although a nightsoil product and possibly contaminated with eggs, might likewise have created conditions that were too hot, alkaline, or dry for egg development.

Landscape and behavioral changes intertwined to modify environmental conditions that differentially impacted the health of urban dwellers. Those with the means to adopt better sanitary technology, move food production out of their back lots, or live in areas with more groomed vegetation were less likely to be parasitized. The nature of urban spaces, however, selected for the more dangerous Ascaris parasite, and for the people vulnerable to acquiring such infections, especially children of the urban poor, those infections may have taken an increasing toll.

\section{Conclusions}

Archaeoparasitological data from sites in the Northeast provide evidence of the shift from Trichuris trichiura to Ascaris lumbricoides, the two most common human parasites recovered archaeologically. Changes in the nature and use of urban spaces differentially influenced these parasites and corresponded to dimensions of class and status as changes in food production strategies and access to sanitation were influenced by wealth and social standing. In his study of New England towns, Mrozowski (2006) found these changes were foreshadowed in the eighteenth century but became particularly apparent in the nineteenth century. In New York, sewer installation began in 1853 , with wealthy areas connected first (Geismar 1993). Serviced 
last, the urban poor continued their reliance upon privies and cesspools, which may have meant more opportunities to become exposed to parasite eggs. Changes to urban landscapes meant that the overwhelming majority of poor urban dwellers found themselves living in increasingly more densely settled urban enclaves, where sanitation remained essentially "premodern" and did not feel the benefits of improving domestic technologies until the turn of the century or sometime thereafter (Beaudry and Mrozowski 2001; Mrozowski 1991, 2006). Some households resisted technology, such as indoor plumbing, because their inhabitants thought that sewer gases contributed to disease and because they considered it an unwanted governmental intrusion into private affairs (Ford 1994). Such beliefs may have contributed to the continued presence of parasites and uneven distribution of parasite loads among households.

Cultural practices, such as changing the use of space around homes, where most parasite infections are acquired, for food production, waste disposal, or ornamental purposes, may have reduced the transmission of parasites for those households with the ability to make such changes. Likewise, deliberate attempts to address health problems - removal of waste outside of cities, the use of sewers, and the creation of highly managed parks, which changed vegetation structure, would have reduced the exposure to parasites or created environments that did not favor their development.

Among the greatest impacts are both the inadvertent and deliberate changes to the distribution of vegetation, which may impact parasite viability and transmission. The nature of changing urban conditions, while affecting the transmission of both, appears to be more detrimental to Trichuris. Given the biology and environmental tolerances of the parasites, the increasing heat and dryness of urban areas may have selectively culled Trichuris eggs that were in the soil. Ascaris eggs may have been better able to survive urbanizing environments and, therefore, more likely to have been able to cause infections. Another characteristic of urban environments is the presence of highly varied microclimates. Such variation may provide local reservoirs for Trichuris ova and may influence the diversity of parasite loads from individual to individual or household to household, thus accounting for the continued presence of Trichuris infections and variability that we see in the archaeological record at different sites.

The shift from Trichuris to Ascaris has implications for the health of those vulnerable to parasite diseases. The acquisition of parasites from the immediate area in and around the house would have meant that poorer households, especially the children, would more likely have been exposed than wealthier households (Mrozowski 1991, 2006). Brooker et al. (2006) notes that contemporary parasite burdens are uneven, with a few heavily infected individuals often contributing the most to community parasite loads. These conditions, and the shift to the more dangerous Ascaris, may have played a role in the perception of densely inhabited urban areas as unhealthy and unsanitary. In the nineteenth century, such portrayals were perpetrated for political purposes (Mayne 1993; Yamin 2000), but the environmental reality of urban spaces may have nonetheless aided in this view, as urban children may have been at greater risk for serious disease. Children playing outdoors, especially if sickly because of parasites, may have provided a visible indication of the health of the neighborhood.

As data presented by Fisher and colleagues (2007) and our broader analysis suggest, it may well be that human populations are becoming increasingly less parasitized through time. Yet today's world remains one in which class and wealth continue to impact the biological wellbeing of many, especially those living in cities. Parasitological data from current populations illustrate that Ascaris in particular remains a problem in poor urban areas that lack modern sanitation (Hotez et al. 2003:11). The archaeoparasitological data reveal the intricate way that social and biological variables intersected to create landscapes of inequality. Nineteenth-century slums may have been a political construction, but biological realities influenced the types of parasites people carried. Parasite data reveal the intimate nature of biological patterns that contribute to the inequities that were a critical part of nineteenth-century urbanization. At an even broader level, these data reflect the way 
large-scale human action can affect the close interaction of parasites and their human hosts. One of the more profound characteristics of urbanization was the shift from mixed commercial-residential areas that were economically diverse to more homogeneous but more rigidly class-differentiated neighborhoods in which social inequalities increasingly resulted in inferior living conditions for the poor, patterns we would today label as examples of environmental and spatial injustice (Soja 2010). The spatially uneven but nevertheless accelerated quality of the changes revealed in the parasite data point to the close relationship between humans and their surroundings. They also suggest trends that could prove more troublesome in the future as more and more people live in cities.

Acknowledgments. The authors are indebted to Karl Reinhard, Pathoecology and Palynology Lab, School of Natural Resources, University of Nebraska, Lincoln, who collected a considerable percentage of data used in this paper and graciously offered additional data. His extensive comments greatly improved the manuscript.

Data Availability Statement. All data used in this study are presented here.

\section{References Cited}

Alcoforado, Maria, and Henrique Andrade

2008 Global Warming and Urban Heat Island. In Urban Ecology: An International Perspective on Humans and Nature, edited by John Marzluff, Eric Shulenberger, Wilfried Endlicher, Marian Alberti, Gordon Bradley, Clare Ryan, Craig ZumBrunnen, and Ute Simon, pp. 249-262. Springer, Boston.

Araújo, Adauto, Karl Reinhard, Luis Ferreira, and Scott Gardner.

2008 Parasites as Probes for Prehistoric Human Migrations? Trends in Parasitology 24:112-115.

Ash, Lawrence, and Thomas Orihel

1990 Atlas of Human Parasitology. American Society of Clinical Pathologists Press, Chicago, Illinois.

Bakta, I., I. Widjana, and P. Sutisna

1993 Some Epidemiological Aspects of Hookworm Infection among the Rural Population of Bali, Indonesia. Southeast Asian Journal of Tropical Medicine and Public Health 24:87-93.

Beaudry, Mary, and Stephen Mrozowski

2001 Cultural Space and Worker Identity in the Company City: Nineteenth-Century Lowell, Massachusetts. In The Archaeology of Urban Landscapes: Explorations in Slumland, edited by Alan Mayne and Tim Murray, pp. 118-131. Cambridge University Press, Cambridge.
Beaver, Paul

1975 Biology of Soil-Transmitted Helminthes: The Massive Infection. Health Laboratory Science 12:116125.

Bethony, Jeffrey, Simon Brooker, Marco Albonico, Stefan, M. Geiger, Alex Loukas, David Diemert, and Peter Hotez

2006 Soil-Transmitted Helminth Infections: Ascariasis, Trichuriasis, and Hookworm. Lancet 367:1521-1532.

Bouchet, Françoise, Stéphanie Harter, and Matthieu Le Bailly 2003 The State of the Art of Paleoparasitological Research in the Old World. Memorias do Instituto Oswaldo Cruz 98:95-101.

Bradley, David, and Anne Keymer

1984 Parasitic Diseases: Measurement and Mortality Impact. Population and Development Review 10:163187.

Brooker, Simon, Neal Alexander, Stefan Geiger, Rana Moyeed, Julian Stander, Fiona Fleming, Peter Hotez, Rodrigo Correa-Oliveira, and Jeffrey Bethony

2006 Contrasting Patterns in the Small-Scale Heterogeneity of Human Helminth Infections in Urban and Rural Environments in Brazil. International Journal of Parasitology 36:1143-1151.

Brown, H., and W. Cort

1927 The Egg Production of Ascaris lumbricoides. Journal of Parasitology 14:88-90.

Bundy, D., and E. Cooper

1989 Trichuris and Trichuriasis in Humans. Advances in Parasitology 28:107-173.

Davey, T.

1966 A Guide to Human Parasitology for Medical Practitioners. 8th ed. Williams and Wilkins, Philadelphia, Pennsylvania.

Dodman, David, Donald Brown, Katie Francis, Jorgelina Hardoy, Cassidy Johnson, and David Satterthwaite

2013 Understanding the Nature and Scale of Urban Risk in Low- and Middle-Income Countries and Its Implications for Humanitarian Preparedness, Planning and Response. Human Settlements Discussion Paper Series: Climate Change and Cities 4. International Institute for Environment and Development, London.

Driscoll, Leslie

1994 Privy unto What Has Passed: The Applications and Limitations of Parasitology. Master's thesis, Department of History, University of Massachusetts, Boston.

Duffy, John

1990 The Sanitarians. University of Illinois Press, Champaign.

Dufour, Benjamin, and Matthieu Le Bailly

2013 Testing New Parasite Egg Extraction Methods in Paleoparasitology and an Attempt at Quantification. International Journal of Paleopathology 3: 199-203.

Fisher, Charles, Karl Reinhard, Matthew Kirk, and Justin DiVirgilio

2007 Privies and Parasites: The Archaeology of Health Conditions in Albany, New York. Historical Archaeology 41(4):172-197.

Ford, Benjamin

1994 The Health and Sanitation of Postbellum Harpers Ferry. Historical Archaeology 28(4):49-61.

Fries, Cara R., D. Katherine Beidleman, and Jay Custer 1990 Analysis of Parasites from 19th-Century Privy Contexts, Wilmington, Delaware. North American Archaeologist 11:17-27. 
Fugassa, Martín, Karl Reinhard, Keith Johnson, Scott Gardner, and Mônica Vieira

2011 Parasitism of Prehistoric Humans and Companion Animals from Antelope Cave Mojave County, Arizona. Journal of Parasitology 97:862-867.

Gallagher, Diana

2006 The Widow Pratt Privy, Newport, Rhode Island: An Archaeobotanical and Archaeoparasitological Analysis. Master's thesis, Department of Anthropology, University of Massachusetts, Boston.

Gallagher, Diana, Susan Jacobucci, and Heather Trigg

2008 The Archaeoparasitology of the 44 Joy Street Privy. In Investigating the Heart of a Community: Archaeological Excavations at the African Meeting House, Boston, Massachusetts, edited by David Landon, pp. 147-156. Cultural Resource Management Study No. 22. Andrew Fiske Memorial Center for Archaeological Research, University of Massachusetts, Boston.

Geismar, Joan H.

1993 Where Is Night Soil? Thoughts on an Urban Privy. Historical Archaeology 27(2):57-70.

Gilbert, Oliver

1989 The Ecology of Urban Habitats. Chapman and Hall, London.

Greenwood, E. (editor)

1999 Ecology and Landscape Development: A History of the Mersey Basin. Liverpool University Press, Liverpool.

Heck, Dana, and Joseph Balicki

1998 Katherine Naylor's "House of Office": A Seventeenth-Century Privy. Historical Archaeology 32(3):24-37.

Hevly, Richard, Roger Kelly, Glenn Anderson, and Stanley Olsen

1979 Comparative Effects of Climatic Change, Cultural Impact, and Volcanism in the Paleoecology of Flagstaff, Arizona, AD 900-1300. In Volcanic Activity and Human Ecology, edited by Payson Sheets and Donald Grayson, pp. 487-523. Academic Press, New York.

Hinz, Erhard

1988 Geomedical Aspects of Parasitology. In Parasitology in Focus: Facts and Trends, edited by Heinz Mehlhorn, pp. 607-618. Springer-Verlag, Berlin. Hodge, Christina

2007 A Middling Gentility: Taste, Status, and Material Culture at the Eighteenth-century Wood Lot, WantonLyman-Hazard Site, Newport, Rhode Island. Ph.D. dissertation, Department of Archaeology, Boston University, Boston, Massachusetts.

Hotez, Peter, Nilanthi de Silva, Simon Brooker, and Jeffrey Bethony

2003 Soil Transmitted Helminth Infections: The Nature, Causes and Burden of the Condition. Working Paper No. 3, Disease Control Priorities Project. Fogarty International Center, National Institutes of Health, Bethesda, Maryland.

Jacobucci, Susan

2009 Parasitological Analysis of Samples from Cross Street Privy, Boston, and Wanton-Lyman Hazard House Privy, Newport. Manuscript on file, Paleoethnobotany Lab, Andrew Fiske Memorial Center for Archaeological Research, University of Massachusetts, Boston.

Jensen, Peter, Pham Phuc, Flemming Konradsen, Lise Klank, and Anders Dalsgaard

2009 Survival of Ascaris Eggs and Hygienic Quality of Human Excreta in Vietnamese Composting
Latrines. Environmental Health 8:57. Electronic document, http://ehjournal.biomedcentral.com/articles/10. 1186/1476-069X-8-57, accessed March 7, 2008.

Jiménez, Blanca

2007 Helminth Ova Control in Sludge: A Review. Water Science and Technology 55(9):147-155.

Jiménez, F. Agustín, Scott Gardner, Adauto Araújo, Martín Fugassa, Richard Brooks, Elizabeth Rácz, and Karl Reinhard

2012 Zoonotic and Human Parasites of Inhabitants of Cueva de Los Muertos Chiquitos, Rio Zape Valley, Durango, México. Journal of Parasitology 98:304309.

Jones, Andrew

1985 Trichurid Ova in Archaeological Deposits: Their Value as Indicators of Ancient Feces. In Paleobiological Investigations: Research Design, Methods, and Data Analysis, edited by N. Fieller, D. Gilberston, and N. Ralph, pp. 105-114. Symposia of the Association for Environmental Archaeology No. 5B. BAR International Series 266, Oxford.

Jones, Andrew, Andrew Hutchinson, and Colin Nicholson

1988 The Worms of Roman Horses and Other Finds of Intestinal Parasite Eggs from Unpromising Deposits. Antiquity 62:275-276.

Keiser, Jennifer, and Jürg Utzinger

2008 Efficacy of Current Drugs against Soil-transmitted Helminth Infections: Systematic Review and Metaanalysis. Journal of the American Medical Association 299:1937-1948.

Kumm, Kelsey, Karl Reinhard, Dario Piombino-Mascali, and Adauto Araújo

2010 Archaeoparasitological Investigations of a Mummy from Sicily (18th-19th Century AD). Anthropologie: International Journal of Human Diversity and Evolution 48:177-184.

Leles, Daniela, Karl Reinhard, Martin Fugassa, Luis Ferreira, Alena Iñiguez, and Adauto Araújo

2010 A Parasitological Paradox: Why is Ascarid Infection so Rare in the Prehistoric Americas? Journal of Archaeological Science 37:1510 1520.

Mackin-Rogalska, R., Jan Pinowski, Jerzy Solon, and Z. Wojcik

1988 Changes in Vegetation, Avifauna, and Small Mammals in a Suburban Habitat. Polish Ecological Studies 14:293-330.

Maya, C., M. Ortiz, and B. Jiménez

2010 Viability of Ascaris and other Helminth Genera Non-Larval Eggs in Different Conditions of Temperature, Lime $(\mathrm{pH})$ and Humidity. Water Science and Technology 62:2616-2624.

Mayne, Alan

1993 The Imagined Slum: Newspaper Representation in Three Cities, 1870-1914. Leicester University Press, Leicester.

Melosi, Martin

2008 Sanitary City: Environmental Services in Urban America from Colonial Times to the Present. University of Pittsburgh Press, Pittsburgh, Pennsylvania.

Mrozowski, Stephen, A.

1987 Exploring New England's Evolving Urban Landscape. In Living in Cities: Current Research in Urban Archaeology, edited by Edward Staski, pp. 1-9. Special Publication of the Society for Historical Archaeology No. 5, Pleasant Hill, California. 
1991 Landscapes of Inequality. In The Archaeology of Inequality, edited by Randall McGuire and Robert Paynter, pp. 79-101. Blackwell, Oxford.

2006 The Archaeology of Class in Urban America. Cambridge University Press, New York.

2014 Imagining an Archaeology of the Future: Capitalism and Colonialism Past and Present. International Journal of Historical Archaeology 18:340-360.

Ndamukong, K.

2005 Epidemiology of Intestinal Nematodes in Schoolage Children of the Kumba Urban Area, South West Cameroon. East African Medical Journal 82: 559-564.

Nolf, L.

1932 Experimental Studies on Certain Factors Influencing the Development and Viability of the Ova of the Human Trichuris as Compared with Those of the Human Ascaris. American Journal of Epidemiology 16:288322.

Pecson, Brian, José Barrios, Blanca Jiménez, and Kara Nelson

2007 The Effects of Temperature, pH, and Ammonia Concentration on the Inactivation of Ascaris Eggs in Sewage Sludge. Water Research 41:2893-2902.

Pickett, S., M. Cadenasso, J. Grove, C. Nilon, R. Pouyat, W. Zipperer, and R. Costanza

2001 Urban Ecological Systems: Linking Terrestrial Ecological, Physical, and Socioeconomic Components of Metropolitan Areas. Annual Review of Ecological Systematics 32:127-157.

Pike, Alan

1968 Recovery of Helminth Eggs from Archaeological Excavations, and Their Possible Usefulness in Providing Evidence for the Purpose of an Occupation. Nature 219:303-304.

Rácz, S., Elisa Pucu, E. Jensen, C. Mostek, Johnica Morrow, M. van Hove, R. Bianucci, D. Willems, F. Heller, Adauto Araújo, and Karl Reinhard

2015 Parasitology in an Archaeological Context: Analysis of Medieval Burials in Nivelles, Belgium. Journal of Archaeological Science 53:304-315.

Reinhard, Karl

1985 Parasitism at Antelope House, a Puebloan Village in Canyon de Chelly, Arizona. In Health and Disease in the Prehistoric Southwest, edited by Charles Merbs and Robert Miller, pp. 234-242. Arizona State University Press, Tucson.

1988 Cultural Ecology of Prehistoric Parasitism on the Colorado Plateau as Evidenced by Coprology. American Journal of Physical Anthropology 77:355366.

1989 Parasitological Analyses of Latrine Soils from the Boott Mills Boardinghouse Site, Lowell, Massachusetts. Interdisciplinary Investigations of the Boott Mills, Lowell, Massachusetts Vol. 3, edited by Mary Beaudry and Stephen Mrozowski, pp. 270-272. Cultural Resource Management Study No. 21. Division of Cultural Resources, North Atlantic Regional Office, National Park Service, Boston, Massachusetts.

1992 Parasitology as an Interpretive Tool in Archaeology. American Antiquity 57:231-245.

1994 Sanitation and Parasitism at Harpers Ferry, West Virginia. Historical Archaeology 28(4):62-67.

2000 Parasitic Disease at Five Points: Parasitological Analysis of Sediments from the Courthouse Block. In Tales of Five Points: Working-Class Life in
Nineteenth-Century New York, Vol. II: An Interpretive Approach to Understanding Working-Class Life, edited by Rebecca Yamin, pp. 391-404. John Milner Associates, West Chester, Pennsylvania.

2007 Microfossil Analysis of Sediment Samples from Sleepy Hollow Senior Housing Project, Sleepy Hollow, New York. PathoEcology Services. Submitted to Hartgen Archaeological Associates, Inc. Albany, New York.

2008 Pathoecology of Two Ancestral Pueblo Villages. In Case Studies in Environmental Archaeology, 2nd ed., edited by Elizabeth Reitz, pp. 191-210. Plenum Press, New York.

Reinhard, Karl, and Adauto Araújo

2012 Synthesizing Archaeology with Parasitology in Paleopathology. In A Global History of Paleopathology, edited by Jane Buikstra and Charlotte Roberts, pp. 751764. Oxford University Press, Oxford.

Reinhard, Karl, Ulisses Confalonieri, Bernd Herrmann, Luis Ferreira, and Adauto Araújo

1986 Recovery of Parasite Remains from Coprolites and Latrines: Aspects of Paleoparasitological Technique. Homo 37:217-239.

Reinhard, Karl, Luis Ferreira, Françoise Bouchet, L. Sianto, J. Dutra, Alena Iñiguez, Daniela Leles, Matthieu Le Bailly, Martín Fugassa, Elisa Pucu, and Adauto Araújo 2013 Food, Parasites, and Epidemiological Transitions: A Broad Perspective. International Journal of Paleopathology 3:150-157.

Reinhard, Karl, Stephen Mrozowski, and Kathy Orloski 1986 Privies, Pollen, Parasites, and Seeds, a Biological Nexus in Historic Archaeology. Masca Journal 4(1):3136.

Roberts, Daniel, and David Barrett

1984 Nightsoil Disposal Practices of the 19th Century and the Origin of Artifacts in the Plowzone Proveniences. Historical Archaeology 18(1):108115.

Rudolfs, Willem, Lloyd Falk, and Robert Ragotzkie

1950 Literature Review on the Occurrence and Survival of Enteric, Pathogenic, and Related Organisms in Soil, Water, Sewage, and Sludges, and on Vegetation: II. Animal Parasites. Sewage and Industrial Wastes 22:14171427.

Searcey, Nicole, Karl, Reinhard, Eduard, Egarter-Vigl, Frank, Maixner, Dario, Piombino-Mascali, Albert, Zink, Winjnand, van derSanden, Scott, Gardner, and Raffaella, Bianucci

2013 Parasitism of the Zweeloo Woman Bog Body. International Journal of Paleopathology 3:224 228.

Shammas, Carole

2000 The Space Problem in Early United States Cities. William and Mary Quarterly 57(3):505-542.

Soja, Edward

2010 Seeking Spatial Justice. University of Minnesota Press, Minneapolis.

Spindler, L.

1929 The Relation of Moisture to the Distribution of Human Trichuris and Ascaris. American Journal of Hygiene 10:476-496.

Szczygiel, Bonj, and Robert Hewitt

2000 Nineteenth-Century Medical Landscapes: John H. Rauch, Frederick Law Olmsted, and the Search for Salubrity. Bulletin of the History of Medicine 74:708734. 
Tarr, Joel

1975 From City to Farm: Urban Wastes and the American Farmer. Agricultural History 49:598-612.

Trigg, Heather, and Susan Jacobucci

2008 Urbanization and Human Parasites: Implications for Health in Urban Communities. Poster presented at the 73rd Meeting of the Society for American Archaeology, Vancouver.

Warnock, Peter, and Karl Reinhard

1992 Methods for Extracting Pollen and Parasite Eggs from Latrine Soils. Journal of Archaeological Science 19:261-264.

World Health Organization (WHO)

1981 Intestinal Protozoan and Helminthic Infections: Report of a WHO Scientific Group. World Health
Organization Technical Report Series 666. World Health Organization, Geneva.

2012 Research Priorities for Helminth Infections: Technical Report of the TDR Disease Reference Group on Helminth Infections No. 972. World Health Organization, Geneva.

Yamin, Rebecca (editor)

2000 Tales of Five Points: Working-Class Life in Nineteenth-Century New York. John Milner Associates, West Chester, Pennsylvania.

Submitted April 14, 2016; Revised January 9, 2017;

Accepted January 17, 2017 